\title{
Smart Shift from Photovoltaic to Agrivoltaic System for Land-Use
}

\section{Footprint}

\section{Nimay Chandra Giri', Ramesh Chandra Mohanty ${ }^{{ }_{2}}$, Siba Prasad Mishra3}

${ }^{1}$ Department of Electrical and Electronics Engineering, Centurion University of Technologyand Management, Odisha, India

${ }^{2}$ Department of Mechanical Engineering, Centurion University of Technology and Management, Odisha, India

${ }^{3}$ Department of Civil Engineering, Centurion University of Technology and Management, Odisha, India

Keywords: Agriculture, PV generation, Rainwater harvesting, Solar farming

\section{Introduction:}

Globally, it is estimated that about 1 billion people are deprived of electricity, and 2.5 billion people are still in queue to have access to sustainable domestic cooking and heating by electricity (World Bank, 2020). According to the 15th report of Sustainable Development Goals (SDG), out of a total of 7.7 billion in the globe, 2.6 billion people have their livelihood quenched from native agriculture as a source. The model results indicate that energy consumption will be increased by almost $55 \%$ by 2050 (IRENA, 2019; RISE, 2020; SDG, 2020). SDG indicator 2.4.1, indicates "Sustainable Agriculture" with three main goals such as environmental health, economic profitability, and social equity. For the development of a country, the greatest challenge is to access reliable energy, food and

\section{Abstract}

The fossil fuel sources are highly supportive for boosting a country's economy but have destructive bearings like spatially exhaustive, global warming, atmospheric greenhouse gas pollution, acid rain and ecosystem destroyer. The problems caused by hydrocarbon sources can only be ameliorated by renewable energy sources like solar, aeolian or geothermal, especially solar energy. Solar energy shall be the prime source of energy in future but demands a huge quantum of land for installations. Simultaneous energy generation and underneath selective agriculture adaptation is novice research. This is an innovative venture of energy generation nexus with food production so that the burden of the land requirement is diminished. The agrivoltaic is considered suitable to the areas in the tropics with resilient irradiation and comparatively less productive arable lands for plant cultivation. The system can also harvest rainwater and biomass from the installed solar panels, a source for irrigation to the plants underneath, clean solar panels, and enhance production. The developing country, India ranks 2nd globally in agricultural products. More than $50 \%$ of the Indian workforce depends on it and contributed about $20 \%$ to the country's GDP. The country's ambition is to implement more agrivoltaic systems in the vast arid lands. Parallel to contemporary energy rates, an agrivoltaic farmer can supply the consumers @5 INR/kWh and sell the agricultural harvest. Overall, the power generation, water accumulated for irrigation, and crop production ratio can be optimized by installing a technoecological agrivoltaic system in the farmers' land.

water in a particular area and also to fulfil the requirement of SDG 7 , recommended in the United Nations Conference (SDG, 2020). Intergovernmental Panel on Climate Change (IPCC), has reported about $60 \%$ of Green House Gas (GHG) emitted from the energy sector. At present only about $17 \%$ of energy use is met from renewable energy and predicted to surge up the generation to $85 \%$ by 2050 to mitigate the harsh impact of climate changes (IPCC, 2020; WEO, 2020; WB, 2020). With the growth of the middle class in India and China, there will be a combined demand for the above parameters. Growing demand for sustainable power productions (especially solar) will improve land use and add values to the economic and social necessity of the human race (ESMAP, 2019; GOI, 2021). About 70 nations claim excellent status for their solar PV installations, and

*Corresponding Author:rcmohanty@cutm.ac.in 
their average output per day surpasses $4.5 \mathrm{kWh}$ per installed kW capacity (GOI, 2021; Dinesh \& Pearce, 2016; Movellan, 2013).

The limitation to the arable land, rampant population growth and surging demand for more land leads to a new horizon of land use, space constraint, socio-economic and ecologic conflicts. Extensive researches explored an innovation agriphotovoltaic (APV) or agrivoltaic system (AVS) where the agricultural land is dually used for rising crops and solar installations for mutual benefits (Santra et al., 2017; Shemkus, 2019). The innovation and implementation of AVS projects were demonstrated by countries such as Japan, 2004 (Othman et al., 2018), USA, 2008 (Fraunhofer, 2018; Xue et al.,2017), Malaysia, 2014 (Dinesh\& Pearce, 2016; Malu et al., 2017), Germany, 2015 (Park, 2019), China, 2016 (GoI, 2021), and India, 2017 (GoI, 2019), and South Korea, 2019 (Hemalatha, 2020), as presented in Table-2.

India is a fast developing country in both agriculture and solar power production after Parish Agreement 2016. The country's solar installed capacity has been surged up generating $38.79 \mathrm{GW}$ by January 2021. Almost $70 \%$ of the country's population depends on agriculture; industries are focusing on better crop production and more employability (PV Magazine, 2019). The government of India (GoI) and German are considering the APV system as a reliable production of energy, simultaneous use of food and water in a single land (Weselek et al., 2019; Marrou et al., 2015). In 2017, a $105 \mathrm{~kW}$ AVS was designed, installed, and tested for real settings as per the Indian Council of Agricultural Research (ICAR) and the Central Arid Zone Research Institute (CAZRI) (Santra et al., 2018; Santra et al., 2018). Apart from $105 \mathrm{~kW}$ AVS, more than twenty gridinteractive AVS were implemented in India by 2020 (Malu et al., 2017; Xue et al., 2017; Irie et al., 2019).

Some figure and facts :The agrivoltaic structure has become an unabated technological resolution for adoption in present agriculture to combat concurrent climate changes. It blends that on the same land, the suitable PV panels, proper solar radiation and the selected low height crops plantation should be managed to optimize potential utilization of the land by retaining the ecosystems (World Bank, 2020). Armin Zastrow and Adolf Goetzberger (1981) was the founder of the concept of agriculture with PV system i.e. "agriphotovoltaics (APV)" (IRENA, 2019; RISE, 2020). Various countries like China, France, Japan, USA, and Malaysia have announced policies about supportive AVS innovations and implementations by 2015. The Government of India (GoI) considers the APV installations are the most dependable energy production for water, food, and energy in a suitable plot (SDG, 2020; IPCC, 2020; WEI, 2020; World Bank, 2020; ESMAP, 2019). AVS installations of about 2200 numbers (177 GW) have been completed worldwide by

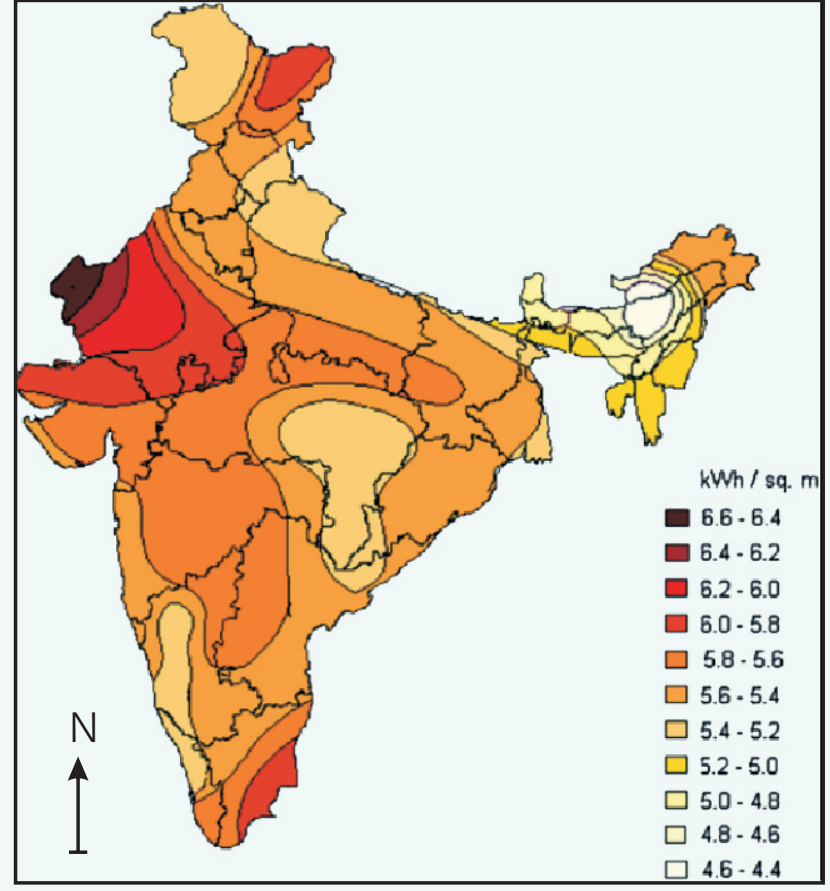

Figure-1: Irradiance map of India (ESMAP, 2019)

2014 as per International Agency's Photovoltaic Power Systems Programme (IEA-PVPS) (GoI, 2021; Dinesh\& Pearce, 2016; Movellan, 2013; Santra et al., 2017). India has augmented its AVS installation capacity of about $3 \mathrm{GW}$ by January 2020 (Ministry of Power, 2021) (Shemkus, 2019; Othman et al., 2018). The solar irradiance map of India is demonstrated in Fig.-1.

The mainland of India extends between 804' and 3706' N latitude and $68^{\circ} 77^{\prime}$ and $97^{\circ} 25^{\prime} \mathrm{E}$ longitude (Fraunhofer, 2018; Xue et al., 2017; Malu et al., 2017; Park, 2019). The solar radiation intensity in an average received in India is calculated to be $0.2 \mathrm{GW} / \mathrm{km}^{2}$. India has a geographical area of 3.287 million $\mathrm{km}^{2}$ and produces 0.6574 million GW power. Most part of India receives high intensity of solar radiation with an average of $5 \mathrm{kWh} / \mathrm{m}^{2} /$ day (ESMAP, 2019; GoI, 2021; Weselek et al., 2019).

There exist three basic forms of agrivoltaics structure which can be explored to generate energy. They are solar arrays with the provision of space for crops underneath, slanted solar array installation overlain crops land and solar array enclosed within greenhouse environment (GoI, 2019; Hemalatha, 2020). All three arrangements of agrivoltaics have numerous parameters which need to be optimized like solar energy simultaneous incidence on the panels and the crops. The two major parameters are taken in the present research of agrivoltaic system are the tilt angle of solar panels and suitable choice of the location depending on the crops, panel heights, solar irradiation and local climate (PV Magazine, 2019; Weselek et al., 2019, Santra et al., 2018; Amaducci, 2018). The comparison of the 
traditional solar power plant and agrivoltaic systems are presented in Table-1.

Table-1: Comparison between traditional solar power plants and agrivoltaic systems

\begin{tabular}{lll}
\hline \# & Traditional solarplants & Agrivoltaic systems \\
1 Only PV & PV+Agriculture \\
2 Bigland use footprint & $\begin{array}{l}\text { Land use footprint solutions } \\
\text { Increase power, food, water and } \\
\text { biomass production }\end{array}$ \\
& Lnlypower production & Soss soiling loss \\
5 Morewater consumption & Less water consumption \\
6 Available of micro- & Mitigate micro-climate climate \\
particles particles & Output efficiency 70-80\% & Efficiencyincreases 40-50\% extra \\
8 Payback period 6-8years & Payback period 4-6years \\
\hline
\end{tabular}

\section{Configuration of AVS:}

Efficient configuration of AVS system helps to optimize the production of energy, food and water in the same area. The following points to be considered;

- Southerly orientation of fixed solar panels or axially rotating east-west panels

- Supportive elevation and adequate spacing between panels for requisite solar light for the crops underneath.

Generally, Solar PV panels are installed at a fixed-tilt angle equal to the latitude of the suitable location for producing maximum power at the output (Pulipaka et al., 2020; Harinarayana \&Vasavi, 2014).

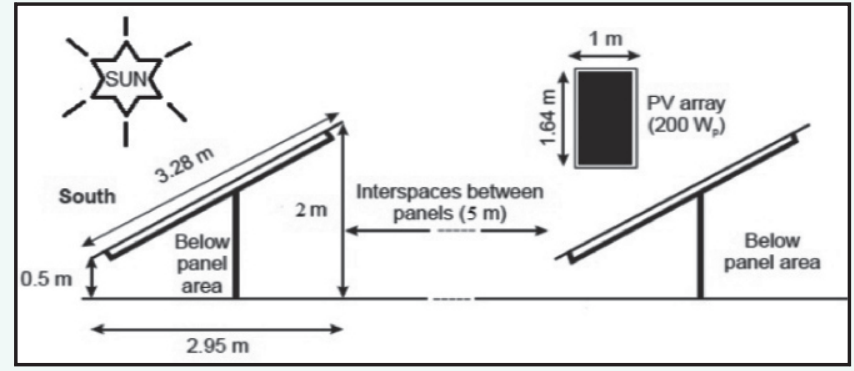

Figure-2: Basic design of agrivoltaic system

The Fig.-2 describes the basic design of solar PV panel installation in an agrivoltaic system. In general, low height mounting structure (ground clearance of $0.5 \mathrm{~m}$ ) with suitable space between two rows (5-10 m) of solar PVarrays to escape the shadow of it on next row. The suitable crops can grow in between two rows easily (UNCCD, 2017; Campen et al., 2000; Talbot et al., 2014).

\section{Fixed Solar Panels over Crops:}

The simple and easy methods of installations is fixed solar panels for agriculture, (when the crops underlain or the crops within the gaps). There is a necessity to optimize structural installation arrangements for the tilting type solar panels (Miskin et al., 2014; Adeh et al., 2019; Nakoul, 2014; Marrou etal., 2015; Malu et al., 2017).

\section{Dynamic Agrivoltaic:}

This is one of the most intricate arrangements. Uses of tracking or mobile structural installations are needed for this type of agrivoltaic system. The control of the solar panels desired to be optimized for their sitting which can increase concurrent agricultural and energy production (Xue et al., 2017; Irie et al., 2019; Barron-Gafford, 2019; Schindele et al., 2020; Ott et al., 2020).

Japan was the first nation to develop a dynamic agrivoltaic system with manually operative panels for controlling solar inputs. The position of the solar panels can only be adjusted manually by the farmers conferring to the season or stage of crop development. The manually operated system could regulate power generation along with a requirement for shading (Ketzer et al., 2020; Giri et al., 2020).

Considering Fig.-2 and features, the installation of a solar power plant requires a large amount of land around 3.5 acres or 1.42 hectare for a $1 \mathrm{MW}$ plant. Design parameters for the installation of solar panels in AVS are a little different from those in a conventional solar power plant (Gaikwad \& Sharma, 2018; Sharpe et al., 2020; Pandey et al., 2018; Proctor et al., 2021; Teo \& Go, 2021). Solar PV panels should be installed on fixed or dynamic iron or GI angle structure facing perpendicular to the south with specified tilt angle (Giri \& Mishra, 2017; Trommsdorff et al., 2021; IBEF, 2020), as demonstrated in Figure 2. Installation of such systems in farmers' land may raise extra income from the sale of electricity and crop production. This has been predicted that 350 to $700 \mathrm{~kW}$ capacity systems may be established in 3.5 acres or 1.42 hectare cropped land (Weselek et al., 2019; Ketzer et al., 2020; Younas et al., 2019). In April 2016, the first experimental design of the AVS system commissioned with a capacity of a $1 \mathrm{MW}$ power plant at Amrol, Gujarat (Kalita et al., 2019; City Air New, 2018; Czaloun, 2017; SolAgra, 2019). The solar panels are installed on a mounting structure at a height of 3 meters. Tilting of panels is carried out manually and the adjustment period is within a gap of 2 months. These plant structures differing inter-module ( $0.05 \mathrm{~m}$ or $5 \mathrm{~cm}$ ) and inter-array gaps ( $4 \mathrm{~m}$ or $400 \mathrm{~cm}$ ) for studying the bearings of various shading patterns during crop growth (Pulipaka et al., 2020; Proctor et al., 2021; Omar et al., 2014).

\section{PV-based Electricity Generation from AVS:}

At Amrol, average solar irradiation and sunny hour available is $6 \mathrm{kWh} /$ day and 7 to 8 hour/day. It is assessed that a $1 \mathrm{~kW}$ PV system can generate $7-8 \mathrm{kWh} /$ day. The installed AVS has been connected to the local grid to sell electricity with a tariff rate of INR 3.44/ $\mathrm{kWh}$ in 2019 (Santra et al., 2018; Bano \& Rao, 2016). The schematic diagram of the PV based electricity generation from the installed AVS is described in Fig.-3. 


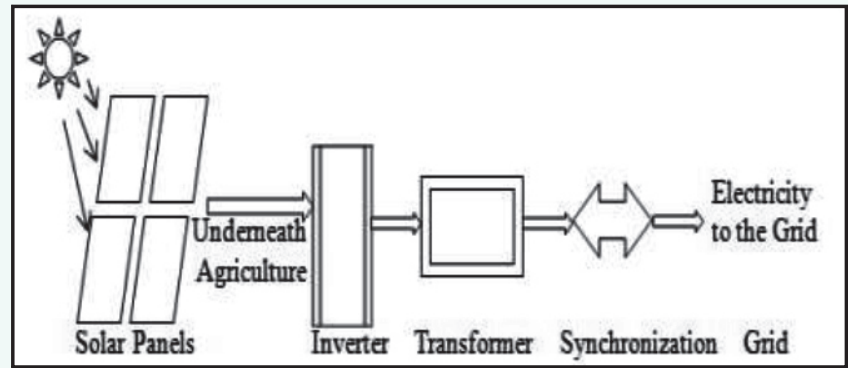

Figure-3: Schematic diagram of power generation in agrivoltaic system

\section{Crop Production in AVS:}

In practice, SPV panels are needed to be tilted by an angle of $\pm 5^{\circ}$ or $\pm 10^{\circ}$ (depending on latitude) in AVS to the ground. Thus, the shade of PV panel is spawned on the sheltered sideways on the ground in accordance with the sun movement during daytime (Kumar \& Sudhakar, 2015; Hariri et al., 2020; Giri, 2019; Suman \& Ahamad, 2018). The gap area amidst two PV arrays (suitable 5-10 $\mathrm{m}$ ) is utilized to grow appropriate low height crops. The availability of PAR (Photosynthetically active radiation) on the shielded ground was assessed considerably which is lowered by 84.5 to $127 \mathrm{mmol} / \mathrm{cm}^{2} / \mathrm{sec}$ in comparison to open sun values of 243-1296 mmol/ $\mathrm{cm}^{2} / \mathrm{sec}$ at ICAR-CAZRI, Jodhpur (Santra et al., 2018; Saddique et al., 2019). More than 40 crops were tested in this AVS such as moth bean (Vigna aconitifolia), mung bean (Vigna radiata), and cluster bean (Cyamopsis tetragonoloba). Besides these rain-fed Kharif produces, limited pharmaceutical plants have been cultivated such as Aloe Vera saplings, sonamukhi (Cassia angustifolia) and eggplant (Solanum melongena) (Santra et al., 2018; Sekiyama \& Nagashima, 2019; Al-agele et al., 2021), as demonstrated in Fig.-4. Vegetable crops can also be cultivated below the panels. It is observed that suitable crops or plant cultivation is predictable to modify the micro-climates and also reducing the temperature. Thus,

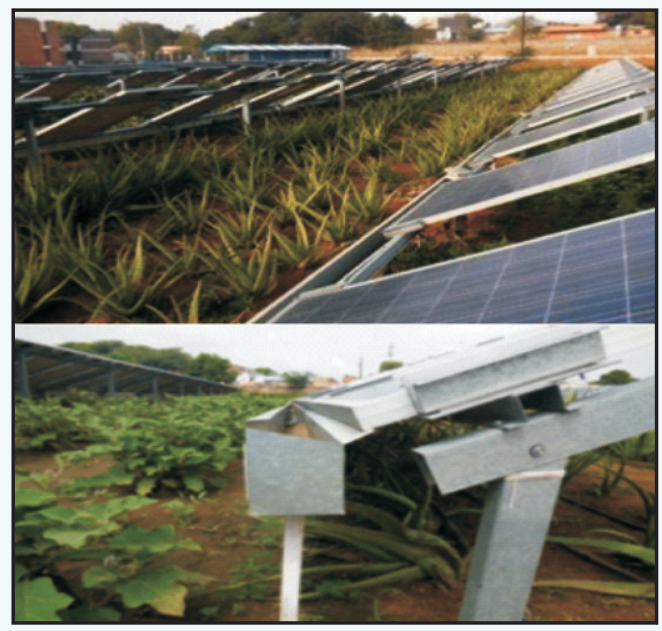

Figure-4(a,b): Crop (Aloe vera and eggplant) cultivation in agrivoltaic system (Source: ICAR-CAZRI)
AVS can optimize both electricity and food production in the same land (Santra et al., 2018; Awan et al., 2020; Menon \& Yokohama, 2020).

\section{Rainwater Harvesting in AVS:}

This is also possible to collect and store precipitations from the PV panel surfaces in AVS. Therefore, a rainwater harvesting system in the developed $1 \mathrm{MW}$ AVS has also been planned and installed (Pascaris et al., 2020; Adeh et al., 2019). The system for water harvesting sources consists of conical Mild Steel (MS) sheet for water collection, and underground water conveying Polyvinyl Chloride (PVC) pipes of 8-inch dia is connected to the storage system. Total water consumption in the storage tank is about 200000 litres/MWp/year capacity (GoI, 2021; Santra et al., 2018; Weselek et al., 2021). This will be used in the cultivation of crops. Thus, the farmer can optimize their cultivation and socio-economic in the same land, as demonstrated in Fig. -5 .

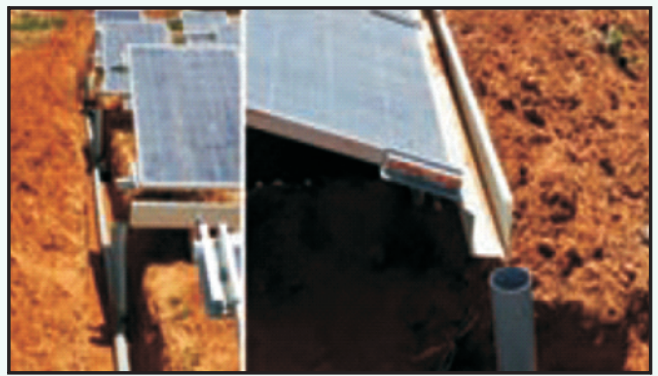

Figure-5: Rainwater harvesting system in agrivoltaic system (Santra et al., 2018)

\section{Discusion:}

The limitation to the arable land, rampant population growth and surging demand for more land leads to a new horizon of land use, space constraint, socio-economic and ecologic conflicts. Extensive researches explored an innovation agriphotovoltaic (APV) or agrivoltaic system (AVS) where the agriculture land is dually used for rising crops and solar installations for mutual benefits. The additional advantage of agriculture with PV installations in arid areas shall reduce GHG emission and dust elimination of the panels and conserve soil moisture simultaneously (Patel et al., 2018; Majumdar \& Pasqualetti, 2017 Elamri et al., 2018). The innovation and implementation of AVS projects were demonstrated by many countries, as presented in Table-2.

The AVS application will likely to be affect crop cultivation and agricultural yield. It is pertinent to account for its impact on the technological features, and operating processes in ground controls, and the simultaneous impact of AVS during changing microclimatic conditions. The consequences of crop cultivation are discussed in the presentstudy.

Agriculture is possible below $(\approx 24 \%)$ and within 
interspace $(\approx 49 \%)$ areas of agriphotovoltaic area and simultaneous harvesting of rainwater can be done for the crops to be cultivated. Researches reveal that some specific crops that grow in arid areas can be possible such as cumin, isabgol, grapes, chickpea, and some varieties of beans such as cluster bean, mungbean, and moth bean (Santra et al., 2018).

Table-2: Global agrivoltaic innovation and implementation scenarios

\begin{tabular}{llll}
\hline$\#$ & Country Name & Implemented on & Capacity \\
1 & Japan & 2004 & $49 \cdot 9 \mathrm{~kW}$ \\
2 & Austria & 2007 & $20 \mathrm{~kW}$ \\
3 & USA & 2008 & $3 \mathrm{MW}$ \\
4 & Denmark & 2014 & $33 \mathrm{~kW}$ \\
5 & Malaysia & 2014 & $1 \mathrm{MW}$ \\
6 & Germany & 2015 & $194.4 \mathrm{~kW}$ \\
7 & China & 2016 & $500 \mathrm{~kW}$ \\
8 & India & 2017 & $1 \mathrm{MW}$ \\
9 & Croatia & 2017 & $500 \mathrm{~kW}$ \\
10 & South Korea & 2019 & $1 \mathrm{MW}$ \\
\hline
\end{tabular}

Expected drawbacks include the very high cost of installation, the safety of the agriculture workers, and complexity in the management of power amalgamated with agriculture, cost allocation and sharing of the benefit. There is a chance of affecting the neighbouring farmers in AVS installations (Harinarayana \& Vasavi, 2014).

The PV energy generation involves the end- user than orthodox grid supply system, the role of farmers and the end- users do not get their proper share so the fixation of ownership is a difficult tax and the programme may fail during field implementation (Campen et al., 200o).

\section{Conclusion:}

With fixed land, exponential population hike, modernization with more energy requirement need can be substituted by the twofold use of land in AVS systems. Hence, there is vast scope for techno-social and optimization in energy, food and water productions, as it's still in its primary stages. India has the future prospect and multiple options for this type agrivoltaic system for the vast arid lands of Punjab, Rajasthan, Gujarat, and Haryana. A suitable implementation of agrivoltaic systems leads to better income for the farmer's, efficiency increases to $40-50 \%$ extra and the payback period of the solar plant will be reduced to half. Even the mountainous hills of Odisha can be tried with AVS installations. Verities of area-specific crops and multiple installations photovoltaic trees (higher altitude) and arrays need to be verified in test fields and the effects need to be monitored. However, there will be several techno-economic, environmental and social challenges faced in sustainable development that would be addressed in future. There is a great future for theAVS.

\section{References:}

Adeh, E.H., Good, S.P., Calaf, M. \& Higgins, C.W. (2019): Solar PV power potential is greatest over croplands. Sci. Reports. 9(1); 11442.

Al-agele, H.A., Proctor, K., Murthy, G. \& Higgins, C. (2021): A Case Study of Tomato (Solanum lycopersicon var. Legend) Production and Water Productivity in Agrivoltaic Systems. Sustainability, 13(5);2850.

Amaducci, S., Yin X., \& Colauzzi, M. (2018): Agrivoltaic systems to optimise land use for electric energy production. Appl. Energy. 220; 545-561.

Awan, A.B., Alghassab M., Zubair, M. Bhatti, A.R., Uzair, M. \& Abbas, G. (2020): Comparative Analysis of Ground-Mounted vs. Rooftop Photovoltaic Systems Optimized for Interrow Distance between Parallel Arrays. Energies.13(14);3639.

Bano, T. \& Rao, K.V.S. (2016): Performance analysis of 1 MW grid connected photovoltaic power plant in Jaipur, India. Energy Eff. Technol. Sustain., IEEE-Explore.165-170.

Barron-Gafford, G.A. (2019): Agrivoltaics provide mutual benefits across the food-energy-water nexus in drylands. Nature Sustain., 2(9).

Campen, B.V., Guidi, D. \& Best, G. (200o): Solar photovoltaics for sustainable agriculture and rural development. Environ. Natural Resourc. Working Paper. No. 2, FAO, Rome.

City Air New (2018): Farmers to maximize profit through 'AgriVoltaic: a Solar Energy and Harvesting Project'. www.cityairnews.com.

Czaloun, G. (2017): A rope rack for PV modules. PV Europe. https://www.pveurope.eu/

Dinesh, H. \& Pearce, J.M. (2016): The potential of Agrivoltaic systems. Renew. Sustain. Energy Rev., 54:299-308.

Elamri, Y., Cheviron, B., Mange, A., Dejean, C., Liron, F. \& Belaud, G. (2018): Rain concentration and sheltering effect of solar panels on cultivated plots. Hydrol. Earth Sys. Sci., 22(2):12851298.

Energy Sector Management Assistance Program (ESMAP) (2019): Global Solar Atlas 2.o: Technical Report. Washington, DC: World Bank. http://documentsı.worldbank.org

Fraunhofer ISE, Photovoltaics and Photosynthesis - Pilot Plant at Lake Constance Combines Electricity and Crop Production. Fraunhofer Institute for Solar Energy Systems ISE.

Gaikwad, S. \& Sharma, K. (2018): Seed germination and the respective enzyme activities in it: a Case study of L. Ambient Sci., 05(2):18-22.

Giri, N.C. (2019): Analysis and designing of 1 MW SPV gross metering power plant in Odisha. Int. J. Emerg. Technol. Innov. Res., 6(6):608-619.

Giri, N.C. \& Mishra, S.P. (2017): Energy remediation by alternate dissemination: SPV/PSO power in India. Int. J. Current Res., 9(8):56391-56397.

Giri, N.C., Mishra, S.P. \& Mohanty, R.C. (2020): Performance parameters, optimization, and recommendation in large scale on-Grid SPV power plant, Odisha, India. Int. J. Mod. Agricul., 9(4):159-167.

Government of India (GoI) (2019): Ministry of New and Renewable Energy (MNRE)-Physical Progress 


\section{REVIEW ARTICLE}

(Achievements). https://mnre.gov.in

Government of India (GoI) (2021): Agriculture, Ministry of Agriculture \& Farmers Welfare (MoAFE). http://agriculture.gov.in/

Government of India (GoI) (2021): Energy, Ministry of Power (MoP). https://powermin.nic.in/

Government of India (GoI) (2021): Ministry of New and Renewable Energy (MNRE). (Ann. Report 2019-20). https://mnre.gov.in

Harinarayana, T. \& Vasavi K.S.V. (2014): Solar energy generation using agriculture cultivated lands. Smart Grid Renew. Energy 5(02):31-42

Hariri, M.H.M., Mat Desa, M.K., Masri, S. \& Zainuri, M.A.A.M. (2020): Grid-Connected PV Generation SystemComponents and Challenges: A Review. Energies, 13:4279.

Hemalatha, K. (2020): Government plans to increase height of solar panels so farming can continue below: if India is to generate $100 \mathrm{GW}$ of solar power by 2022 , it is only a matter of time before agricultural land also goes under. The Wire 2019 https://thewire.in

Indian Brand Equity Foundation (IBEF) (2020): Agriculture in India: Agricultural Exports \& Food Industry in India.

Intergovernmental Panel on Climate Change (IPCC) (2020): AR6 Synthesis Report: Climate Change 2022. www.ibef.org

International Renewable Energy Agency (IRENA) (2019): Global Energy Transformation:A roadmap to 2050.www.ipcc.ch

Irie, N., Kawahara, N. \& Esteves, A.M. (2019): Sector-wide social impact scoping of agrivoltaic systems: A case study in Japan. Renew. Energy., 139:463-1476.

Kalita, P., Das, S., Das, D., Borgohain, P., Dewan, A. \& Banik, R.K. (2019): Feasibility study of installation of MW level grid connected solar photovoltaic power plant for northeastern region of India. Sadhana, 44(207):1-24.

Ketzer, D., Schlyterc, P., Weinbergera, N., Röscha, C. (2020): Driving and restraining forces for the implementation of the Agrophotovoltaics system technology - A system dynamics analysis. J. Environ. Manag., 270:110864.

Kumar, B.S. \& Sudhakar, K. (2015). Performance evaluation of 10 MW grid connected solar photovoltaic power plant in India. Energy Reports, 1:184-192.

Majumdar, D. \& Pasqualetti, M. (2017): Dual use of agricultural land: Introducing 'agrivoltaics' in Phoenix Metropolitan Statistical Area, USA. Landsc. Urban Plan., 170.

Malu, P.R., Sharma, U.S. \& Pearce, J.M. (2017): Agrivoltaic potential on grape farms in India. Sustain. Energy Tech. Assess., 23:104-110.

Marrou, H., Guilioni, L., Dufour, L., Dupraz, C. \& Wery, J. (2015): Microclimate in agrivoltaic systems: is crop growth rate affected in the partial shade of solar Panels? Agricul. Forest Meteorol., 201(1):177-178.

Menon, N. \& Yokohama (2020): 'Solar sharing': lessons from Japan for India's green energy and pollution crisis. Fast Asia. www.eastasiaforum.org

Miskin, C.K., Li, Y., Perna, A., Ellis, R.G., Grubbs, E.K., Bermel, P. and Agrawal, R. (2019): Sustainable co-production of food and solar power to relax land-use constraints. Nature Sustain., 2(10):972-980.
Ambient Science, 2021: Vol. 08(2); 12-18 DOI:10.21276/ambi.2021.08.2.rv01

Movellan, J. (2013): Japan next-generation farmers cultivate crops and solar energy. www.renewableenergyworld.com

Nakoul, Z. (2014): Optimization of a Solar Photovoltaic Applied to Greenhouses. Physics Procedia., 55:383-389.

Omar, E., Haitham, A.R. \& Frede, B. (2014): Renewable energy resources: Current status, future prospects and their enabling technology. Renew. Sustain. Energy Rev., 39:748-749.

Othman, N.F., Su, M.A.S. \& Ya'acob, M.E. (2018): Promising potentials of Agrivoltaic systems for the development of Malaysia Green Economy. IOP Conference Series: Earth Environ. Sci. 146(1):012002.

Ott, E.M., Kabus, C.A., Baxter, B.D., Hannon, B., Celik, I. (2020): Environmental analysis of agrivoltaic systems. Reference Module in Earth Systems and Environmental Sciences. Pub. by: Elsevier.

Pandey, A., Tiwari, D., Yadav, D.K., Mishra, R.K., Deshpande, V.P. \& Shinde, A. (2018): StabilizationofSoilunderFoundationand Pavements Using FlyAsh. Ambient Sci., 05(2):08-11.

Park, J. (2019): Governmental measures and directions of renewable energy policy in Korea: Speaker. Jeonnam Agricultural Research and Extension Service (JARES) South Korea.International symposium on solar energy in the form of farming, Republic of Korea.

Pascaris, A.S., Schelly, C., \& Pearce, J.M. (2020): A First Investigation of Agriculture Sector Perspectives on the Opportunities and Barriers for Agrivoltaics. Agronomy, 10(12):1885.

Patel, B., Gami, B., Baria, V., Patel, A., \& Patel, A. (2018): CoGeneration of Solar Electricity and Agriculture Produce by Photovoltaic and Photosynthesis-Dual Model by Abellon, India. J. Solar Energy Eng., 141(3):01014-01021.

Proctor, K., Tabatabaie, S.M.H. \& Murthy, G.S. (2021): Gateway to the perspectives of the Food-Energy-Water nexus. Sci. Total Environ.,764:142852.

Pulipaka, S. \& Peparthy, M. (2020): Agrivoltaics in India Overview of operational Projects and relevant Policies. Indo-German Energy Forum Support Office (IGEF-SO). Report by: National Solar Energy Federation of India (NSEFI). www.energyforum.in

PV Magazine. (2019):Brandbrief von neungrünen Energieministern an Altmaierfüermehr Photovoltaik. www.pv-magazine.de

Regulatory Indicators for Sustainable Energy (RISE) (2020): Sustaining the Momentum. https://rise.esmap.org

Saddique, Q., Cai, H., Ishaque, W., Chen, H., Chau, H.W., Chattha, M.U., Hassan, M.U., Khan, M.I. \& He, J. (2019): Optimizing the Sowing Date and Irrigation Strategy to Improve Maize Yield by Using CERES (Crop Estimation through Resource and Environment Synthesis)-Maize Model. Agronomy, 9(2):109.

Shemkus, S. (2019): Agrivoltaics: solar panels on farms could be a win-win: Massachusetts is leading the charge in dual-use solar installations, making it possible to grow some crops and pasture animals while generating clean energy. Pub. by: Civil Eat

Santra, P., Singh, R.K., Jain, D. \& Yadav, O.P. (2018): Agri-voltaic system to enhance land productivity and income. Indian Farm., 68(09):108-111. 
Santra, P., Singh, R.K., Meena, H.M., Kumawat, R.N., Mishra, D., Jain, D. \& Yadav, O.P. (2018): Agri-voltaic system: crop production and photovoltaic-based electricity generation from a single land unit. Indian Farm., 68(01):20-23.

Santra, P., Pande, P.C., Kumar, S., Mishra, D. \& Singh, R.K. (2017): Agri-voltaics or Solar farming: the Concept of Integrating Solar PV Based Electricity Generation and Crop Production in a Single Land use System. Int. J. Renew. Energy Res., 7(2):694699.

Schindele, S., Trommsdorff, M., Schlaaka, A., Obergfell, T., Bopp, G., Reise, C., Brauna, C., Weselek, A., Bauerle, A., Högy, P., Goetzberger, A. \& Weber, E. (2020): Implementation of agrophotovoltaics: Techno-economic analysis of the priceperformance ratio and its policy implications. Appl. Energy. 265:114737.

Sekiyama, T. \& Nagashima, A. (2019): Solar Sharing for Both Food and Clean Energy Production: Performance of Agrivoltaic Systems for Corn, A Typical Shade-Intolerant Crop. Environments, 6(6):65.

Sharpe, K.T., Heins, B.J., Buchanan, E.S., \& Reese, M.H. (2020): Evaluation of solar photovoltaic systems to shade cows in a pasture-based dairy herd.J. Dairy Sci.,104 (3):2794-2806.

SolAgra (2019): Solagra Farming and the Sunsharing Revolution. www.solagra.com

Suman, S.K. \& Ahamad, J. (2018). Solar Energy Potential and Future Energy of India: An Overview. Int. J. Comp. Sci. Eng., 8(5):17575-17579.

Sustainable Development Goal (SDG) 15, Life on Land. https://www.undp.org

Sustainable Development Goal (SDG) 7, Affordable and clean energy. www.undp.org/

Talbot, G., Roux, S., Graves, A., Dupraz, C., Marrou, H. \& Wery, J. (2014): Relative Yield Decomposition: A Method for Understanding the Behaviour of Complex Crop Models. Environ. Model. Software, 51:136-48.
Teo, Y.L. \& Go, Y.I. (2021): Techno-Economic-Environmental Analysis of Solar/Hybrid/Storage for Vertical Farming System: A Case Study, Malaysia. Renew. Energy Focus. 37:5067.

The World Bank (2020): Solar Photovoltaic Power Potential by Country. www.worldbank.org

The World Energy Outlook (WEO) (2020): The gold standard of energyanalysis. www.iea.org

Trommsdorff, M., Kang, J., Reisea, C., Schindele, S., Bopp, G., Ehmann, A., Weselek, A., Högy, P. Obergfell, T. (2021): Combining food and energy production: Design of an agrivoltaic system applied in arable and vegetable farming in Germany. Renew. Sustain. Energy Rev.,140:110694.

United Nations Convention to Combat Desertification (UNCCD) (2017): 2030 Agenda for Sustainable Development: implications for the United Nations Convention to Combat Desertification. https://www.unccd.int

Weselek, A., Ehmann, A., Zikeli, S., Lewandowski, I., Schindele, S. \& Högy, P. (2019): Agrophotovoltaic systems: applications, challenges, and opportunities. A review. Agron. Sustain. Develop.,39:35.

Weselek, A., Bauerle, A., Zikeli, S., Lewandowski, I. \& Högy, P. (2021): Effects on crop development, yields and chemical composition of celeriac (Apium graveolens $\mathrm{L}$. var. rapaceum) Cultivated Underneath an Agrivoltaic System. Agronomy.,11(4);773.

Xue, J. (2017): Photovoltaic agriculture - New opportunity for photovoltaic applications in China. Renew. Sustain. Energy Rev., 73:1-9.

Younas, R., Imran, H., Riaz, M.H. \& Butt, N.Z. (2019): Agrivoltaic farm design: vertical bifacial vs. tilted monofacial photovoltaic panels. IEEEAccess. 1-17. 